Tropical Journal of Pharmaceutical Research October 2018; 17 (10): 2073-2077

ISSN: $1596-5996$ (print); 1596-9827 (electronic)

(C) Pharmacotherapy Group, Faculty of Pharmacy, University of Benin, Benin City, 300001 Nigeria.

Available online at http://www.tjpr.org

Original Research Article

http://dx.doi.org/10.4314/tjpr.v17i10.26

\title{
Thyroid function in chronic hepatitis C patients treated with interferon
}

\author{
Ma Dongmei ${ }^{1}$, Pan Zheng ${ }^{2}$ \\ ${ }^{1}$ Department of Nuclear Medicine, ${ }^{2}$ ICU Department of Neurology, Second Hospital of Lanzhou University, Lanzhou City, \\ 730030, China
}

*For correspondence: Email: tw1290@163.com

Sent for review: 4 August 2018

Revised accepted: 29 September 2018

\begin{abstract}
Purpose: To investigate the effect of interferon (IFN) treatment for chronic hepatitis $\mathrm{C}$ (CHC) patients on thyroid function.

Methods: 65 patients (27 males and 38 females, aged 28 - 61 years) with mild or moderate $\mathrm{CHC}$ and early fibrosis admitted to Second Hospital of Lanzhou University from January 2017 to January 2018 were enrolled in this study, while 65 healthy subjects served as the control group. The study group

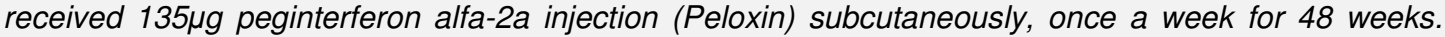
Ribavirin was administered orally once a day at doses ranging from $10-15 \mathrm{mg} / \mathrm{kg}$ body weight. Chemiluminescence immunoassay was used to measure thyroid hormone and antibody levels in both groups.

Results: After interferon therapy, the positive expressions of TGAb and TPOAb in the study group were lower than the corresponding values observed before treatment $\left(X^{2}=8.188, p=0.004 ; X^{2}=11.527, p<\right.$ 0.001). Thyroid hormone levels in the study group were normal before treatment, but free triiodothyronine (FT3) and free thyroxine (FT4) were significantly lower in the study group ( $t 1=-9.58, t 2$ $=-14.61, p<0.001)$. However, FT3 and FT4 significantly increased after treatment in the study group, relative to the control group $(p<0.05)$. The level of TSH in the study group was significantly higher than the level before treatment $(p<0.05)$, but gradually returned to normal.

Conclusion: Chronic hepatitis $C$ patients may have thyroid dysfunction, and IFN therapy may result in transient disorder in thyroid hormone metabolism. Thus, TSH, TGAb and TPOAb can be used as predictors of thyroid disease development during IFN therapy for $\mathrm{CHC}$.
\end{abstract}

Keywords: Chronic hepatitis C, Thyroid hormone, Anti-thyroid autoantibody, Interferon

\begin{abstract}
This is an Open Access article that uses a funding model which does not charge readers or their institutions for access and distributed under the terms of the Creative Commons Attribution License (http://creativecommons.org/licenses/by/4.0) and the Budapest Open Access Initiative (http://www.budapestopenaccessinitiative.org/read), which permit unrestricted use, distribution, and reproduction in any medium, provided the original work is properly credited.

Tropical Journal of Pharmaceutical Research is indexed by Science Citation Index (SciSearch), Scopus, International Pharmaceutical Abstract, Chemical Abstracts, Embase, Index Copernicus, EBSCO, African Index Medicus, JournalSeek, Journal Citation Reports/Science Edition, Directory of Open Access Journals (DOAJ), African Journal Online, Bioline International, Open-J-Gate and Pharmacy Abstracts
\end{abstract}

\section{INTRODUCTION}

Hepatitis $C$ is a common viral hepatitis caused by hepatitis $\mathrm{C}$ virus (HCV) infection. It is a chronic disease often associated with autoimmune damage and extrahepatic lesions such as thyroid abnormalities $[1,2]$. It has been reported that approximately 71 million people (about $1 \%$ of the world's population) have $\mathrm{CHC}$ infection, out of which more than 39,000 people die each year from HCV-related liver disease [3]. Chronic hepatitis $C$ is one of the common causes of liver cirrhosis and hepatocellular carcinoma. There are about 5.6 million cases of hepatitis $C$ in 
China. According to the World Health Organization, $7 \%$ of patients with $\mathrm{CHC}$ were treated worldwide by 2015 [4].

The World Health Organization (WHO) has set a goal to achieve $80 \%$ cure of CHC by 2030 and eliminate HCV [5]. Studies have shown that HCV easily develops into $\mathrm{CHC}$, and then necrosis and fibrosis, as well as complications such as upper gastrointestinal bleeding, ascites infection of the abdominal cavity, and hepatic encephalopathy [6]. In addition, severe cases can develop into cirrhosis and hepatocellular carcinoma, which severely affect the patient's physical and mental health [6]. Since 2014, all oral, direct-acting antiviral drugs (DAAs) used in the treatment of $\mathrm{CHC}$ have high response rates, short duration of treatment, and fewer side effects $[7,8]$.

Prior to the development of DAA, the main treatment for chronic hepatitis $C$ in China was IFN combined with ribavirin. However, IFN produces many adverse reactions in the treatment of chronic viral hepatitis, especially thyroid disease with incidence of $1.9-40.0 \%$ $[9,10]$. Studies have shown that $\mathrm{CHC}$ patients are prone to thyroid disease, which can be aggravated by IFN therapy [11,12]. The present study was carried out to investigate changes in thyroid hormone and thyroid autoantibodies before, during and after antiviral therapy in patients with $\mathrm{CHC}$. It was also aimed at analyzing changes in thyroid function before and after treatment so as to study the effect of antiviral therapy on thyroid function and its clinical significance.

\section{EXPERIMENTAL}

\section{General information on subjects}

Sixty-five patients with mild or moderate chronic hepatitis C, and early liver fibrosis admitted to Second Hospital of Lanzhou University from January 2017 to January 2018 were included in the study group. The clinical diagnosis was based on the 2015 guidelines for the prevention and treatment of chronic hepatitis C. They comprised 27 males and 38 females, aged 28 61 years, with a median age of $40.73 \pm 8.48$ years. All patients had a history of blood products, which were confirmed by quantitative analysis of hepatitis C antibody and HCV RNA. Patients with other underlying diseases were excluded. Sixty-five healthy subjects were selected as the control group. These comprised 24 males and 41 females aged $30-63$ years, with a median age of $42.66 \pm 9.31$ years old. There were no significant difference in gender and age between the two groups $\left(x^{2}=0.290, t=\right.$ $-1.24, p>0.05)$.

\section{Treatment}

The study group received $135 \mu \mathrm{g}$ peginterferon alfa-2a injection (Peloxin) subcutaneously, once a week for 48 weeks. Ribavirin was administered orally once a day at doses of $10-15 \mathrm{mg} / \mathrm{kg}$ body weight. During the course of treatment, adverse reactions in patients were carefully monitored. Patients who were forced to discontinue due to severe myelosuppression, psychiatric symptoms, and autoimmune diseases were excluded. This research was approved by the Ethical Committee of Second Hospital of Lanzhou University (approval no. 20174617) and carried out according to the Declaration of Helsinki promulgated in 1964 as amended in 1996 [13].

\section{Observation indicators}

Blood ( $3 \mathrm{~mL}$ ) was taken from patients before and 6 months after the antiviral treatment, and 3 months after the termination of treatment in the study group. In addition, $3 \mathrm{~mL}$ fasting blood was taken from patients in the control group. The blood samples were allowed to clot, and the sera were used for the assay of FT3, FT4, TSH, TGAb, and anti-TPOAb with German Siemens Chemiluminescence Immunoassay Analyzer kits (ADVIA Centaur XP) in accordance with the manufacturer's protocol.

\section{Statistical analysis}

Statistical analyses were carried out using SPSS 17.0 statistical software. Measurement data were expressed as mean \pm standard deviation (SD), and $t$-test was used for comparison between groups. Count data was expressed as percentage (\%), and compared between groups using chi square $\left(X^{2}\right)$ test. Variance analysis was used for comparison between groups, while LSD $t$-test was used for comparison within groups. Values of $p<0.05$ were considered statistically significant.

\section{RESULTS}

\section{Positive expressions of TGAb and TPOAb}

There were 17 cases of thyroid disease $(26.15$ $\%)$ in the study group, comprising 11 hyperthyroidism and 6 hypothyroidism patients. All patients were diagnosed after endocrine consultation, and symptomatic treatment was given, followed by IFN treatment. 
Table 1: TGAb and TPOAb expression levels before and after treatment in the study group [n (\%)]

\begin{tabular}{lccccc}
\hline \multirow{2}{*}{ Case } & \multirow{2}{*}{$\mathbf{N}$} & \multicolumn{2}{c}{ TGAb } & \multicolumn{2}{c}{ TPOAb } \\
\cline { 3 - 6 } & 11 & $9(13.85)$ & $2(3.08)$ & $10(15.38)$ & $1(1.54)$ \\
\hline Hyperthyroidism & 6 & $5(7.59)$ & $1(1.54)$ & $3(4.62)$ & 0 \\
Hypothyroidism & 17 & $14(21.54)$ & $3(4.62)$ & $13(20.00)$ & $1(1.54)$ \\
\hline Total & $P<0.05$, compared with value before treatment & &
\end{tabular}

In the study group, the positive expressions of TGAb and TPOAb before treatment were 21.54 $\%(14 / 65)$ and $20.00 \%(13 / 65)$, respectively, while in the control group, expressions of TGAb and TPOAb were 0 and $6.15 \%$ (4/65), respectively. There were significant differences in the degree of expressions of TPOAb between the two groups $\left(x^{2}=15.690, p<0.001 ; x^{2}=\right.$ $5.482, p=0.019)$. After treatment, the positive expressions of TGAb and TPOAb in the study group were significantly lower than those before treatment $\left(x^{2}=8.188, p=0.004 ; x^{2}=11.527, p<\right.$ $0.001)$. These results are shown in Table 1.

\section{Thyroid hormone levels}

The thyroid hormone levels in the study group were within the normal range before treatment, but FT3 and FT4 were significantly lower than their corresponding values in the control group $(\mathrm{t} 1=-9.58, \mathrm{t} 2=-14.61, p<0.001$; Table 2). However, FT3, FT4, and TSH levels in the study group were significantly increased after treatment $(p<0.05)$, but TSH level gradually returned to normal with the treatment (Table 3 ).

Table 2: Thyroid hormone levels prior to treatment

\begin{tabular}{lcccc}
\hline Group & Cases & $\begin{array}{c}\text { FT3 } \\
\text { (pmol/L) }\end{array}$ & $\begin{array}{c}\text { FT4 } \\
\text { (pmol/L) }\end{array}$ & $\begin{array}{c}\text { TSH } \\
(\mathbf{m U} / \mathbf{m l})\end{array}$ \\
\hline Control & 65 & $5.77 \pm$ & $16.11 \pm$ & $4.81 \pm$ \\
& & 0.48 & 1.74 & 0.44 \\
Study & 65 & $4.92 \pm$ & $12.36 \pm$ & $4.69 \pm$ \\
$t$ & 0.53 & 1.12 & 0.50 \\
$p$ & & -9.58 & -14.61 & -1.45 \\
\multicolumn{5}{l}{ Values are expressed as mean \pm SD }
\end{tabular}

Table 3: Thyroid hormone levels before, during and after IFN treatment

\begin{tabular}{lccc}
\hline Period & $\begin{array}{c}\text { FT3 } \\
\text { (pmol/L) }\end{array}$ & $\begin{array}{c}\text { FT4 } \\
(\mathbf{p m o l} / \mathbf{L})\end{array}$ & $\begin{array}{c}\text { TSH } \\
(\mathbf{m U} / \mathbf{m l})\end{array}$ \\
\hline Before & $4.92 \pm$ & $12.36 \pm$ & $4.69 \pm$ \\
treatment & 0.53 & 1.12 & 0.50 \\
During & $5.11 \pm$ & $13.21 \pm$ & $9.77 \pm$ \\
treatment & 0.67 & 2.89 & $1.61^{*}$ \\
After & $5.48 \pm$ & $14.61 \pm$ & $4.51 \pm$ \\
treatment & $0.63^{*}$ & $3.33^{*}$ & 0.47 \\
$\mathrm{~F}$ & 14.036 & 12.163 & 567.730 \\
$P$ & $<0.001$ & $<0.001$ & $<0.001$ \\
\hline Values are expressed as mean \pm SD; & $p<0.05$, \\
compared with value prior to treatment &
\end{tabular}


affected, which is consistent with results obtained elsewhere [18-22]. Therefore, patients with chronic hepatitis C may have abnormalities in thyroid hormone and thyroid antibody levels. Thus, the pros and cons should be weighed before IFN treatment, and tests for thyroid hormone and thyroid autoantibodies should be done during routine examination. The results obtained in the present study indicate that these tests would be helpful for predicting the occurrence of thyroid disease during IFN treatment.

\section{DECLARATIONS}

\section{Conflict of Interest}

No conflict of interest associated with this work.

\section{Contribution of Authors}

This work was done by the authors named in this article and the authors accept all liability resulting from claims which relate to this article and its contents. The study was conceived and designed by Pan Zheng; Ma Dongmei, Pan Zheng collected and analysed the data; Ma Dongmei wrote the text and all authors read and approved the text prior to publication.

\section{REFERENCES}

1. Chinese Medical Association Liver Diseases Branch, Chinese Medical Association Infectious Diseases Branch. The guideline of prevention and treatment for hepatitis C: a 2015 update. J Clin Hepatol 2015; 31(12): 1961-1979.

2. Mengwei $Y$, Wenwen $Y$, Liang $D$, Yang $D$, Luyao $W$, Boan L, Han W. Character of change of autoimmune thyroid antibodies titer in patients with chronic hepatitis $C$ related autoimmune thyroid diseases. Chin Med Herald 2017; 14(5): 117-120.

3. World Health Organization. Global hepatitis report, 2017. Geneva: WHO; 2017.

4. Polaris OHCVC. Global prevalence and genotype distribution of hepatitis C virus infection in 2015: a modelling study. Lancet Gastroenterol Hepatol 2017; 2(3): 161-176.

5. Hirnschall G. Update on progress towards elimination targets: are we on track? In: 4th International Conference HIV/Viral Hepatitis Co-Infection Meeting. Paris: France IAS; 2017.

6. Baihai J, Limin C. The role of interferon-stimulated genes in hepatitis $C$ virus replication. Chin $J$ Blood Transfus 2015; 28(10): 1290-1293.

7. Feld JJ, Jacobson IM, Hezode C, Asselah T, Ruane PJ, Gruener N, Abergel A, Mangia A, Lai CL, Chan HL, et al. Sofosbuvirand Velpatasvir for HCV Genotype 1,2,4,5, and 6 Infection. N Engl J Med 2015; 373(27): 25992607.

8. Zeuzem S, Ghalib R, Reddy KR, Pockros PJ, Ben Ari Z, Zhao $Y$, Brown DD, Wan S, DiNubile MJ, Nguyen BY, et al. Grazoprevir-Elbasvir Combination Therapy for Treatment-Naive Cirrhotic and Noncirrhotic Patients With Chronic HCV Genotype 1,4, or 6 Infection: A Randomized Trial. Ann Intern Med 2015; 163(1): 1-13.

9. Yong H, Kim W, Kwon SY, Yu HM, Kim JH, Choe WH. Incidence of and risk factors for thyroid dysfunction during peginterferona and ribavirin treatment in patients with chronic hepatitis C. Korean J Intern Med 2015; 30(6): 792-800.

10. Fredlund P, Hillson J, Gray T, Shemanski L, Dimitrova D, Srinivasan S. Peginterferon Lambda-1a Is Associated with a Low Incidence of Autoimmune Thyroid Disease in Chronic Hepatitis C. J Interferon Cytokine Res 2015; 35(11): 841-843.

11. Yunan S, Fangfang C, Zanan J, Lin Z. Study on thyroid dysfunction caused by interferon therapy in patients with chronic hepatitis C. Chin Pract Med 2015; 10(26): 146148.

12. Yan L, Jiagan $H$, Ning $Y$, Xie N, Lan Z, Wei H, Jiangong $Z$, Boan L, Han W. The changes of autoantibodies in patients with hepatitis $C$ virus related AITD after interferon treatment. Lab Med Clin 2017; 14(1): 4-7.

13. World Health Organization. Declaration of Helsinki. Br Med J 1996; 313(7070): 1448-1449.

14. Miao L, Huafeng C, Menghua L. Study on thyroid hormone and related antibody levels in patients with hepatitis C. Chin Med J Metallogr Ind 2016; 33(2): 242243.

15. Zhenhua Z, Zijie S, Hongguang L, Pei $Y$, Chao $D$. Correlation between thyroid autoimmune antibodies and hepatitis C virus infection. Chin J Nosocomiol 2016; 26(18): 4113-4115.

16. Mastoor K, Ashraf MI, Anwer K, Amjad M. The presence of thyroid auto-antibodies is a risk factor for thyroid dysfunction in chronic hepatitis $C$ patients during treatment with interferon-aand ribavirin. Pak J Med Health Sci 2016; 10(1): 15-18.

17. Minzhen $Y$, Qing $X$, Cuiling $C$. Risk factors of thyroid dysfunction in the anti-virus therapy of chronic hepatitis c. Chin J Clin Pharmacol 2015; 31(16): 1585-1587.

18. Kozielewicz D, Wietlickapiszcz M, Halota W. Long-term outcomes of thyroid dysfunction in patients with chronichepatitis $C$ treated with pegylated interferon alpha and ribavirin. Przegl Epidemiol 2017; 71(4): 555569.

19. Ahmad N, Samo JA, Bhatti HUR. Overt thyroid dysfunction during treatment of hepatitis $C$ patients with Interferon and Ribavirin. Med Forum Monthly 2016; 27(5): 30-32.

20. Xiaojing R, Yuanyuan J, Xun Q, Guoguang X. Efficacy evaluation of peginterferon combined with ribavirin in the treatment of chronic hepatitis $C$ caused by intravenous drug addiction. Chin Hepatol 2017; 22(6): 529-532. 
Dongmei \& Zheng

21. Hou Z, Mu Z, Zhang J, Fan H, Hou J. The Correlation of Blood Lipid Profile and its Ratio, Cystatin $C$ and
Homocysteine of Thyroid Dysfunction. Am J Clin Exp Med 2017; 5(4): 108-114. 